\title{
RADIOCARBON DATING OF GROUNDWATER IN GRANITE FRACTURES IN ABUKUMA PROVINCE, NORTHEAST JAPAN
}

\author{
H A Takahashi ${ }^{1,2} \bullet$ T Nakamura $^{3} \bullet \mathrm{H} \mathrm{Tsukamoto}^{1} \bullet \mathrm{K} \mathrm{Kazahaya}^{1} \bullet \mathrm{H} \mathrm{Handa}^{1} \bullet$ A Hirota $^{1}$
}

ABSTRACT. Knowledge of the groundwater age is indispensable for understanding groundwater flow in crystalline rocks. The present study is the first to discuss the radiocarbon ages of groundwater in Abukuma granite, Fukushima Prefecture, northeast Japan. The vertical profiles of ${ }^{14} \mathrm{C}$ dates and $\delta^{13} \mathrm{C}$ are obtained from 3 boreholes (depths of 140, 230, and $306 \mathrm{~m}$ ). Chemical and carbon isotopic compositions suggest that dead-carbon contamination of groundwater occurred during groundwater storage in the fractures. ${ }^{14} \mathrm{C}$ concentration was corrected by using isotopic mass balance in which dead-carbon contamination of the groundwater was considered. The ${ }^{14} \mathrm{C}$ dates ranged from modern to $\sim 16 \mathrm{ka}$. The relationship between tritium and ${ }^{14} \mathrm{C}$ data in 1 borehole suggests the simultaneous inflow of shallow groundwater to deeper levels occur for the depths between 60 and $100 \mathrm{~m}$. The vertical profiles of ${ }^{14} \mathrm{C}$ dates indicate a relatively constant age of 10-16 ka for groundwater deeper than $100 \mathrm{~m}$, which may have been influenced by rapid sea-level changes after the glacial period.

\section{INTRODUCTION}

Aquifers in crystalline rocks are formed by fracture networks that are governed by the physical properties of rock heterogeneities such as openings, spacings, and connectivity (Berkowitz 2002; de Dreuzy et al. 2004; Neuman 2005). Groundwater resources for such aquifers are rather low in terms of sustainable discharge per productive well compared with that for porous, karstic, and volcanic aquifers (Dewandel et al. 2006). However, crystalline aquifers constitute an important water resource, particularly in semi-arid regions (Gustafson and Krásný 1994). Moreover, because crystalline rocks intrinsically present significantly low hydraulic conductivity, these rock masses are good candidates for nuclear waste storage (Gustafson et al. 2009). Thus, groundwater flow and storage in crystalline rocks are major issues for the research of water management and safety assessment of geological disposal systems of high-level nuclear waste.

Groundwater age (residence time) offers essential information on groundwater flow and storage. Previous studies reported a wide range of groundwater ages in hard rock areas. Ayraud et al. (2008) used chlorofluorocarbon analysis to determine that relatively young groundwater of $\sim 80 \mathrm{yr}$ was situated in a weathered-fissured layer and an underlying deep fractured zone. Bottomley et al. (1990) used ${ }^{14} \mathrm{C}$ and $\mathrm{He}$ age analyses and reported 2 ages. They determined that $\mathrm{Na}-\mathrm{HCO}_{3}$ water was recharged $\sim 10^{4} \mathrm{yr}$ ago and that deep saline water is likely $10^{8} \mathrm{yr}$ old.

The present study discusses the radiocarbon ages of groundwater in the crystalline aquifers sampled from 3 drilling boreholes in the Abukuma granitic province, Fukushima Prefecture, northeast Japan. The source of ${ }^{14} \mathrm{C}$ to groundwater is ${ }^{14} \mathrm{C}$-bearing $\mathrm{CO}_{2}$ gas dissolved in the recharge zone. ${ }^{14} \mathrm{C}$ dating of groundwater requires that dissolved inorganic carbon (DIC) in groundwater occurs without external carbon contamination. However, possibilities of such contamination were discovered in the present study. Numerous calcite veins were observed in the drilling cores of sampling boreholes. Moreover, the existence of geogenic fluid ascent is suggested from the seismic topography reported by Tong et al. (2012), which can also be considered a source of carbon contamination. The present study has the following objectives: (1) examination of external carbon contamination in groundwa-

\footnotetext{
${ }^{1}$ Geological Survey of Japan, National Institute of Advanced Science and Technology, 1-1-1, Higashi, Tsukuba 305-8567, Japan. ${ }^{2}$ Corresponding author. Email: h.a.takahashi@aist.go.jp.

${ }^{3}$ Center for Chronological Research, Nagoya University, Furo-cho, Chikusa-ku, Nagoya, 464-8602, Japan.
} 


\section{H A Takahashi et al.}

ter; (2) correction of contamination from ${ }^{14} \mathrm{C}$ concentration in groundwater, if present; and (3) determination of the ${ }^{14} \mathrm{C}$ ages of groundwater in fractures of Abukuma granite.

\section{SAMPLES AND METHODS}

The present study established 2 sites, Miharu and Shirasawa, in the same rock body of the Abukuma granitic province, northeast Japan (Figure 1). In the study area, the Morioka-Shirakawa geological tectonic line is situated $\sim 1.2 \mathrm{~km}$ east of the Miharu site and $\sim 6 \mathrm{~km}$ east of the Shirasawa site. Several studies reported that existing faults provide pathways for fluids (Ohwada et al. 2007; Umeda et al. 2011), and the Morioka-Shirakawa tectonic line can be considered such a pathway. The ascent of geogenic fluids through the tectonic line beneath the study area could result in the difference between the 2 sites.

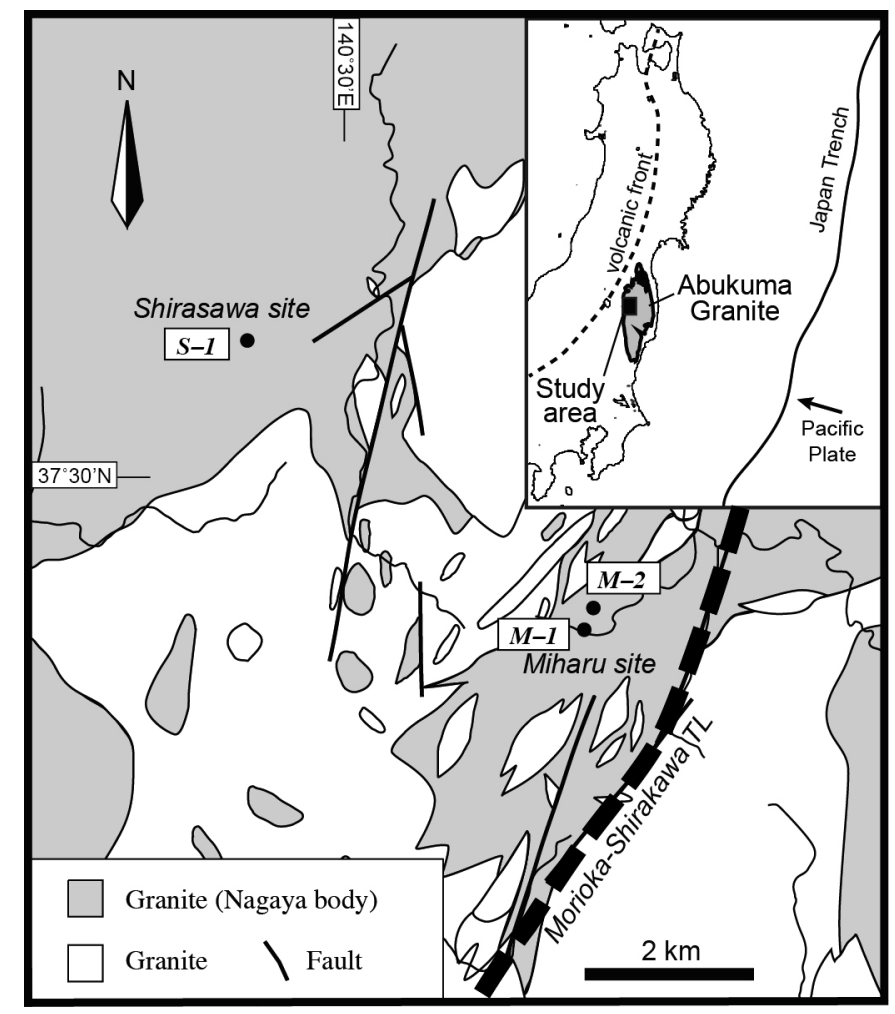

Figure 1 Geological map of study area in the Abukuma granitic province, NE Japan (modified from Kamei and Takagi 2003). The Morioka-Shirakawa tectonic line is represented by the bold dashed line, as indicated by seismic exploration (H Tsukamoto, unpublished data).

Two boreholes at Miharu (M-1 and M-2) and one at Shirasawa (S-1) were drilled (Table 1). To date, few boreholes have been drilled in the Abukuma granite at depths of more than $100 \mathrm{~m}$. The groundwater samples at shallow depths of M-1 and M-2 were obtained by pumping after flushing. In situ sampling of additional samples was conducted using a single- or double-packer system. The sampling reservoir was evacuated before sampling and was inserted into the boreholes. When the reservoir was connected to the packer system in the boreholes, the groundwater sample was drawn through a double-ended sampling needle attached to a rubber septa of sampling reservoir and packer 
system. To reduce the contribution of drilling water and slime contaminations to these samples, presampling procedures were repeated several dozen times with the same sampling system. In most cases, the monitoring pressure of the in situ groundwater decreased and gradually returned. When sampling was conducted at a low-connectivity fracture, the groundwater pressure did not return completely or required a lengthy period for recovery. Although pumping tests were not performed to measure hydraulic conditions, we were able to analogize fracture connectivity from the time interval of pressure recovery. M-1 may have been drilled under tension conditions owing to its location near a step structure of lineaments. The trend of analogized connectivity of fractures is relatively low at M-2 and S-1 and high at M-1.

Table 1 Locality and features of drilling boreholes.

\begin{tabular}{llll}
\hline Borehole & M-1 & M-2 & S-1 \\
\hline Site & Miharu & Miharu & Shirasawa \\
Lat./Long. & $37^{\circ} 29^{\prime} 30.61^{\prime \prime} \mathrm{N}$, & $37^{\circ} 29^{\prime} 35.84^{\prime \prime} \mathrm{N}$, & $37^{\circ} 31^{\prime} 09.59^{\prime \prime} \mathrm{N}$, \\
& $140^{\circ} 31^{\prime} 49.12^{\prime \prime} \mathrm{E}$ & $140^{\circ} 31^{\prime} 49.71^{\prime \prime} \mathrm{E}$ & $140^{\circ} 29^{\prime} 25.06^{\prime \prime} \mathrm{E}$ \\
Altitude (asl) & $366.2 \mathrm{~m}$ & $381.1 \mathrm{~m}$ & $293.7 \mathrm{~m}$ \\
Bottom depth & $306 \mathrm{~m}$ & $140 \mathrm{~m}$ & $230 \mathrm{~m}$ \\
Thickness of soil & $1.6 \mathrm{~m}$ & $0 \mathrm{~m}$ & $0.3 \mathrm{~m}$ \\
\hline
\end{tabular}

To estimate drilling water contamination, $\mathrm{NH}_{4} \mathrm{I}$ as a tracer regent was dissolved in the drilling water. The iodine concentration of drilling water was $20-90 \mathrm{mg} / \mathrm{L}$. The contamination ratio of drilling water was examined by comparing the values of iodine concentration between the drilling water and sampled groundwater. The effects of contamination of drilling water on DIC concentration and isotopic compositions were corrected by calculating the contribution of drilling water contamination as well as the chemical and isotopic compositions of drilling water. The DIC concentration was measured using the acid titration method immediately after sampling. The stable carbon isotopic ratio $\left(\delta^{13} \mathrm{C}\right)$ of DIC, which was conventionally represented with respect to Vienna Pee Dee Belemnite (VPDB), was measured by continuous-flow isotope ratio mass spectrometry (IR-MS) with a gas chromatography system (Delta-V Advantage and GasBench II, Thermo Fisher Scientific Inc.) at the Geological Survey of Japan. $\mathrm{CO}_{2}$ samples were extracted using the headspace method with the addition of phosphoric acid. The measurement error of $\delta^{13} \mathrm{C}$ was better than $0.1 \%$. ${ }^{14} \mathrm{C}$ concentration $\left(\delta^{14} \mathrm{C}\right)$ was measured by accelerator mass spectrometry (model 4130-AMS, HVEE) at the Center for Chronological Research, Nagoya University, with respect to the HOx-II standard. The standard deviation for ${ }^{14} \mathrm{C} /{ }^{12} \mathrm{C}$ reproducibility of $\mathrm{HOx}-\mathrm{II}$ is around $1.6 \%$, which is comparable to counting statistics (Nakamura et al. 2000). Graphite targets were prepared from $\mathrm{CO}_{2}$ reacted from $\mathrm{SrCO}_{3}$, which was precipitated from DIC in groundwater. The ${ }^{14} \mathrm{C}$ dates were calculated following the recommendations of Stuiver and Polach (1977); calibration for calendar age was not conducted. Tritium concentration $\left({ }^{3} \mathrm{H}\right)$, measured by liquid scintillation counters with measurement errors of 3 $15 \%$ at the Geo-Science Laboratory Co. Ltd., Japan, and GNS Science, New Zealand, showed detection limits of 0.3 and $0.04 \mathrm{TU}$, respectively. Calcite veins $(0.01-25 \mathrm{~mm}$ in thickness) were observed at all boreholes beneath the weathered layer. The $\delta^{13} \mathrm{C}$ values of calcite veins from the drilling core at M-1 were measured by continuous-flow IR-MS $(n=6)$.

\section{RESULTS AND DISCUSSION}

\section{Carbon Sources in Groundwater}

The analysis of stable isotopic composition $\left(\delta \mathrm{D}\right.$ and $\left.\delta^{18} \mathrm{O}\right)$ suggests that all groundwater in the present study originated from meteoric water (Figure 2; M Takahashi and M Yasuhara, unpublished 


\section{H A Takahashi et al.}

data). The d-value of the stable isotopic composition of groundwater was lower than that of present local meteoric water (Figure 2). Jouzel et al. (1982) reported that the d-value of the Dome C ice-core was $4.5 \%$ lower around $18,000 \mathrm{yr} \mathrm{BP}$ than that of the past $7500 \mathrm{yr}$. The low d-value in the present study suggests that the groundwater age is of a glacial period. However, the ${ }^{14} \mathrm{C}$ dates described below were inconsistent at the shallow depth. Other effects are needed to explain the low d-value at the shallow depth, but we will not discuss these effects in detail here.

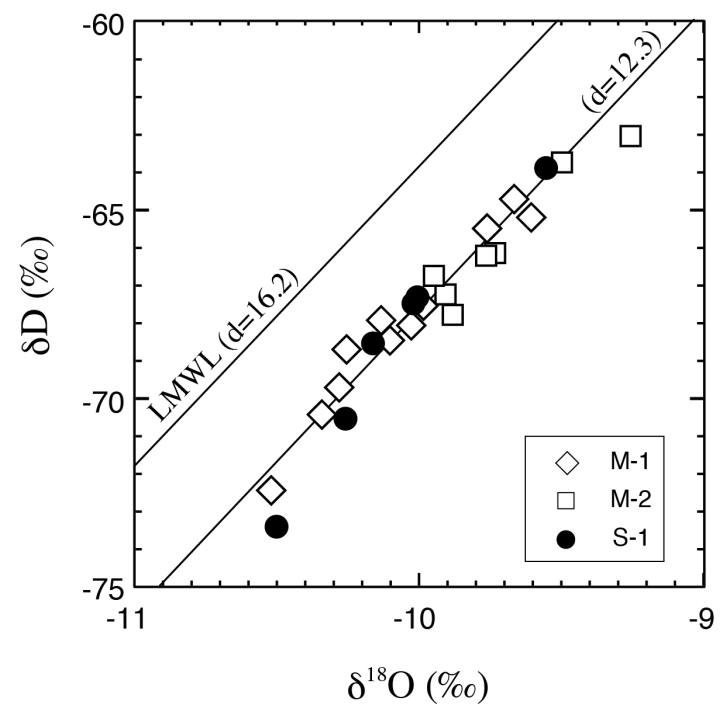

Figure 2 Stable isotopic composition of groundwater samples (M Takahashi, unpublished data) and local meteoric water lines (M Yasuhara, unpublished data).

The ${ }^{14} \mathrm{C}$ concentration is affected by geochemical reactions during DIC evolution and ${ }^{14} \mathrm{C}$ decay. In the recharge zone, the source of DIC in groundwater is soil $\mathrm{CO}_{2}$ dissolution to form the initial carbon. During the DIC evolution, ${ }^{14} \mathrm{C}$ activity is decreased by radioactive decay as well as mixing of non-active carbon (dead carbon) or relatively lower activity carbon (older carbon) from various carbon sources. The external carbon contamination is attributed to the calcite veins in the drilling core and the ascent of geogenic fluid beneath the study site. Thus, the results of ${ }^{14} \mathrm{C}$ dating of groundwater must be corrected for the effects of external carbon admixing.

The isotopic mass balance is a valid approach used to quantify the contamination of external carbon. The $\delta^{13} \mathrm{C}$ values of initial and external carbon are required for isotopic mass balance analysis. The external carbon in the present study was considered to originate from the dissolution of carbonate minerals (calcite veins) in addition to the admixing of geogenic $\mathrm{CO}_{2}$, both of which affected ${ }^{14} \mathrm{C}$ concentration and $\delta^{13} \mathrm{C}$ in groundwater. Carbon sources of both processes may have had a high $\delta^{13} \mathrm{C}$ values (Hoefs 2009) and been ${ }^{14} \mathrm{C}$-free. Moreover, the microbiological oxidation of soil organic matter did not likely provide external carbon because the soil layers at the drilling sites are very thin (Table 1).

\section{Correction of External Carbon}

The present study used the isotopic mass balance to correct for admixing of carbon contamination: 


$$
\begin{gathered}
f=\left(\delta^{13} \mathrm{C}_{m}-\delta^{13} \mathrm{C}_{i}\right) /\left(\delta^{13} \mathrm{C}_{a}-\delta^{13} \mathrm{C}_{i}\right), \\
\delta^{14} \mathrm{C}_{i}=\left(\delta^{14} \mathrm{C}_{m}-f \cdot \delta^{14} \mathrm{C}_{a}\right) /(1-f),
\end{gathered}
$$

where $f$ is the contamination ratio of admixing carbon and subscripts $m, a$, and $i$ are the measured value, admixing carbon, and initial carbon, respectively. For the calculation, the $\delta^{13} \mathrm{C}$ values of admixing and initial carbon must be obtained.

Although the vertical profiles of DIC concentration and $\delta^{13} \mathrm{C}$ were identical in M-1 and M-2, differences were apparent between these samples and S-1 (Figure 3, Table 2), which suggests different carbon sources. Therefore, the Miharu and Shirasawa sites are discussed separately.
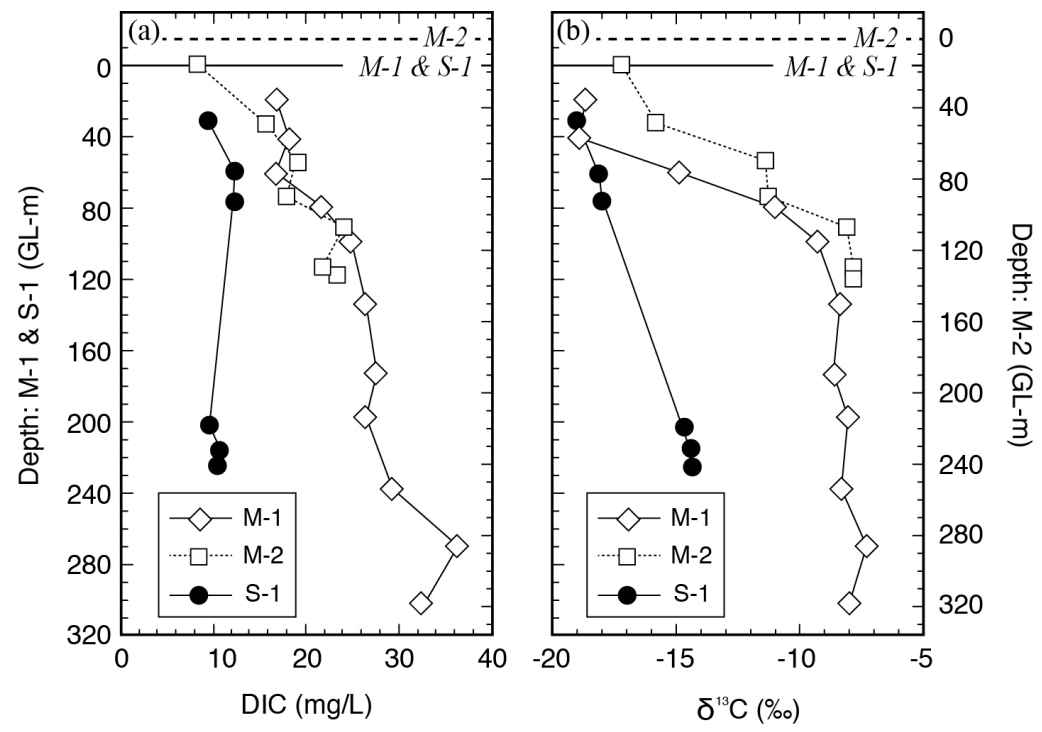

Figure 3 The vertical profiles of DIC concentration (a) and $\delta^{13} \mathrm{C}$ value (b) of groundwater (Miharu site: M-1 and M-2; Shirasawa site: S-1)

\section{Estimation of $\delta^{13} \mathrm{C}$ at Miharu Site}

At Miharu, the vertical increasing trends of the DIC concentration and $\delta^{13} \mathrm{C}$ with depth were measured (Table 2, Figure 3). These results indicate the contamination of external carbon with a high $\delta^{13} \mathrm{C}$ value in groundwater during its storage in granite. The $\delta^{13} \mathrm{C}$ value of external carbon at this site was calculated as $-3.2 \%$ by using a simple mixing model (Figure 4 ; Keeling 1958), which is nearly identical to that of calcite at M-1 $(-4.5 \pm 1.7 \%)$. However, because the lower values of $\mathrm{pH}$ at the Miharu site compared to those at Shirasawa cannot be explained by only calcite dissolution, we consider that $\mathrm{CO}_{2}$ admixing is a reason for this low $\mathrm{pH}$ value. Geochemical simulation by the PHREEQC program (Parkhurst and Appelo 1999) cannot describe the chemical compositions of groundwater (M Takahashi, unpublished data) without the inclusion of such $\mathrm{CO}_{2}$ admixing. At the Shirasawa site, on the contrary, PHREEQC does not require $\mathrm{CO}_{2}$ admixing. The $\delta^{13} \mathrm{C}$ value of admixing $\mathrm{CO}_{2}$ is around $-2 \%$ (1:1 mixing with calcite and admixing $\mathrm{CO}_{2}$ ), which suggests that the admixing $\mathrm{CO}_{2}$ at the Miharu site may be deep-seated. Therefore, the external carbon originated from calcite and geogenic $\mathrm{CO}_{2}$. One possible geogenic source is fluid dehydrated from a subducted slab (Tong et al. 2012). For the calculation of carbon contamination, the mixture component of calcite and geogenic $\mathrm{CO}_{2}$ can be used as an admixing end-member because both are ${ }^{14} \mathrm{C}$-free. 


\section{H A Takahashi et al.}

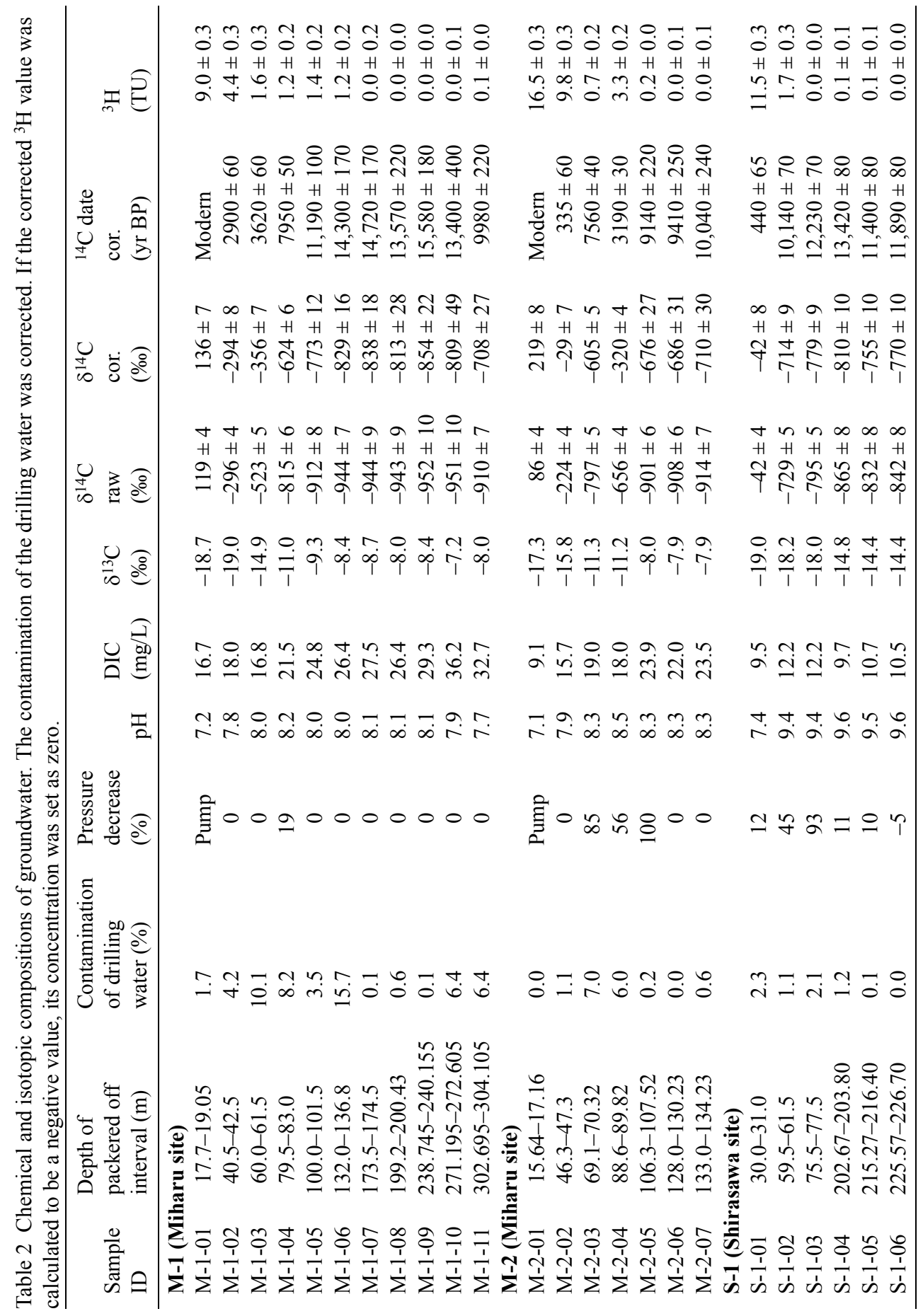




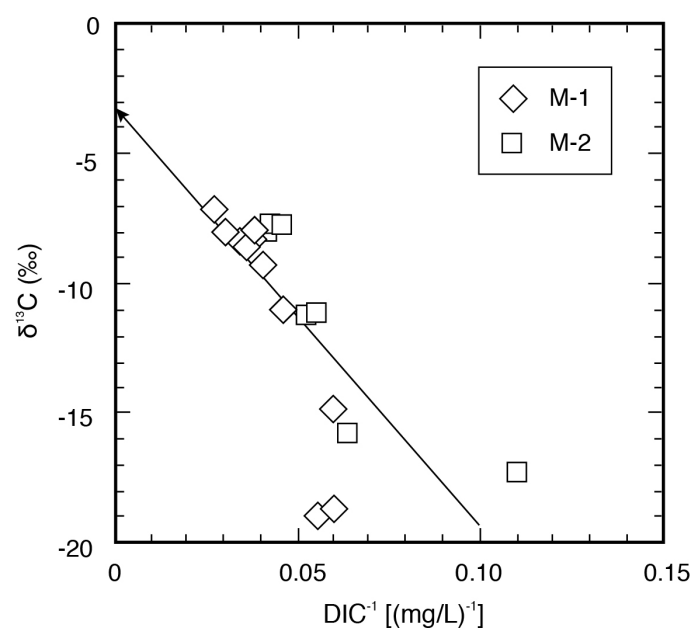

Figure 4 The relationship between the inverse of DIC concentration and $\delta^{13} \mathrm{C}$ of M-1 and M-2. The arrow indicates the regression fit line at the Miharu site.

The $\delta^{13} \mathrm{C}$ value of initial carbon must be assumed to quantify the external carbon contribution. The $\delta^{13} \mathrm{C}_{\text {of }} \mathrm{C}_{3}$ plants ranges from $-32 \%$ to $-22 \%$ (O'Leary 1988). Bird and Pousai (1997) reported the average $\delta^{13} \mathrm{C}$ values of SOC at forest and temperate grasslands to be $-28.4 \pm 0.7 \%$ and $-26.0 \pm$ $1.1 \%$, respectively. In contrast, the isotopic fractionation during $\mathrm{CO}_{2}$ diffusion in soil air, where the process of $\mathrm{CO}_{2}$ respiration occurs, theoretically increases the $\delta^{13} \mathrm{C}$ value of soil $\mathrm{CO}_{2}$ from SOC to 4.4\%o (Davidson 1995). In addition, the effects of $\mathrm{C}_{4}$ plants and isotopic fractionation between DIC and $\mathrm{CO}_{2}$ gas must be considered. Although both effects increase the $\delta^{13} \mathrm{C}$ value of soil $\mathrm{CO}_{2}$ (O'Leary 1988; Zhang et al. 1995; Bird and Pousai 1997), their quantitative influences cannot be obtained. Hence, the measured minimum $\delta^{13} \mathrm{C}$ value of DIC at all boreholes $(-19.0 \%$, Table 2$)$ can be used for the $\delta^{13} \mathrm{C}$ value of initial carbon. The contamination effect of the external carbon at Miharu was corrected by assuming that initial carbon originating from soil $\mathrm{CO}_{2}$ is $-19 \%$ and external carbon calculated by the mixing model is $-3.2 \%$ (Figure 4 ).

\section{Estimation of $\delta^{13} \mathrm{C}$ at Shirasawa Site}

At Shirasawa, the DIC concentration and $\delta^{13} \mathrm{C}$ were constant and relatively low (Table 2, Figure 3). The $\delta^{13} \mathrm{C}$ values of Shirasawa groundwater were nearly consistent with those isotopically equilibrated with soil $\mathrm{CO}_{2}$. Although slightly high $\delta^{13} \mathrm{C}$ values were observed deeper than $200 \mathrm{~m}$ (Table 2, Figure 3), the DIC concentration was nearly constant vertically.

The mechanism that explains both DIC concentration and $\delta^{13} \mathrm{C}$ values beneath depths of $200 \mathrm{~m}$ is the isotopic exchange between DIC in groundwater and calcite minerals in fractures, which affects the carbon isotopic composition without changing the DIC concentration. Because initial calcite is expected to be ${ }^{14} \mathrm{C}$-free, isotopic exchange decreases the ${ }^{14} \mathrm{C}$ concentration in groundwater. Thus, the ${ }^{14} \mathrm{C}$ concentration at Shirasawa should be corrected. Although this process may have also occurred at Miharu, the effect by calcite dissolution was nearly identical to these results; thus, this process was not considered for correction at Miharu. For analysis by isotopic mass balance, the $\delta^{13} \mathrm{C}$ of calcite is required. The $\delta^{13} \mathrm{C}$ value of calcite veins in S-1 was not measured in the present study, but that in $\mathrm{M}-1$ was measured at $-4.5 \pm 1.7 \%$. The effect of isotopic exchange at Shirasawa was cor- 


\section{H A Takahashi et al.}

rected by assuming that initial carbon originating from soil $\mathrm{CO}_{2}$ is $-19 \%$ and exchanged carbon measured from calcite is $-4.5 \%$.

\section{Radiocarbon Dates of Groundwater}

${ }^{14} \mathrm{C}$ concentration was corrected using the contamination ratios of ${ }^{14} \mathrm{C}$-free components, which were calculated by the isotopic mass balance of $\delta^{13} \mathrm{C}$. The vertical profiles of the measured and corrected values of $\delta^{14} \mathrm{C}$ and corrected ${ }^{14} \mathrm{C}$ dates are shown in Figures 5 and 6. Some groundwater samples contained ${ }^{3} \mathrm{H}$ (Table 2). ${ }^{3} \mathrm{H}$ is commonly detected in young groundwater less than $\sim 60 \mathrm{yr}$ old. However, the ${ }^{14} \mathrm{C}$ dates of groundwater containing ${ }^{3} \mathrm{H}$ were significantly older. If ${ }^{3} \mathrm{H}$ indicates actual ages of groundwater, the $\delta^{13} \mathrm{C}$ value of admixing ${ }^{14} \mathrm{C}$-free carbon must range from $-9 \%$ to $-8 \%$ at the Miharu site. This $\delta^{13} \mathrm{C}$ range is not consistent with the relationship between the DIC concentration and $\delta^{13} \mathrm{C}$ (Figure 4). Hence, these values indicate that the shallow, young groundwater mixed with old groundwater in granite factures. The younger ${ }^{14} \mathrm{C}$ date of M-2-04 than that at the shallower depth of M-2-03 is consistent with the high ${ }^{3} \mathrm{H}$ occurring in M-2-04. A pathway with a high porosity fracture likely exists that connects the shallow part to the lowest depths of M-2-04 in the M-2 borehole.
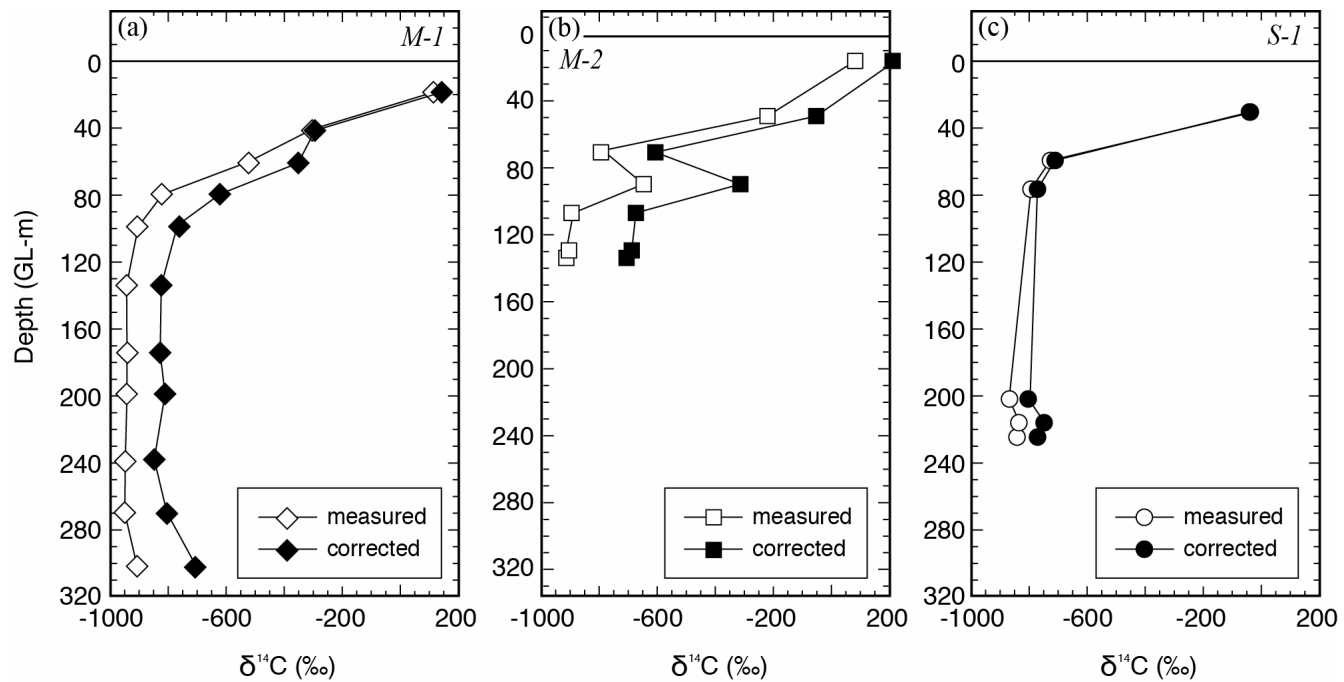

Figure 5 The vertical $\delta^{14} \mathrm{C}$ profiles of DIC in groundwater: (a): M-1; (b): M-2; (c): S-1.

The ${ }^{14} \mathrm{C}$ dates of M-1 at depths between 60 and $100 \mathrm{~m}$ were slightly younger than those of M-2 and $\mathrm{S}-1$ (Figure 6). On the basis of ${ }^{3} \mathrm{H}$ concentration (Table 2), shallow groundwater mixing in $\mathrm{M}-1$ at $136 \mathrm{~m}$ was achieved at depths deeper than those in M-2 $(107 \mathrm{~m})$ and S-1 $(60 \mathrm{~m})$. These results are consistent with the high connectivity of fractures and tension hydraulic conditions at $\mathrm{M}-1 .{ }^{3} \mathrm{H}$ was nearly constant between 60 and $132 \mathrm{~m}$ at M-1, although the $\delta^{14} \mathrm{C}$ values represent vertical gradients with depth (Figure 6). This finding suggests that the inflow of shallow groundwater at those in M-1 $(60$ and $132 \mathrm{~m})$ occurred simultaneously with relatively constant contribution of shallow groundwater, and that the fractures may not have connected with each other. Earthquakes are assumed as triggers for opening fractures and connecting between shallow and deep. The high analogized connectivity of the fracture at M-1 may have influenced the fracture opening, which could explain the discrepancy in the hydraulic data among the boreholes, although the ${ }^{14} \mathrm{C}$ dates did not differ significantly. 


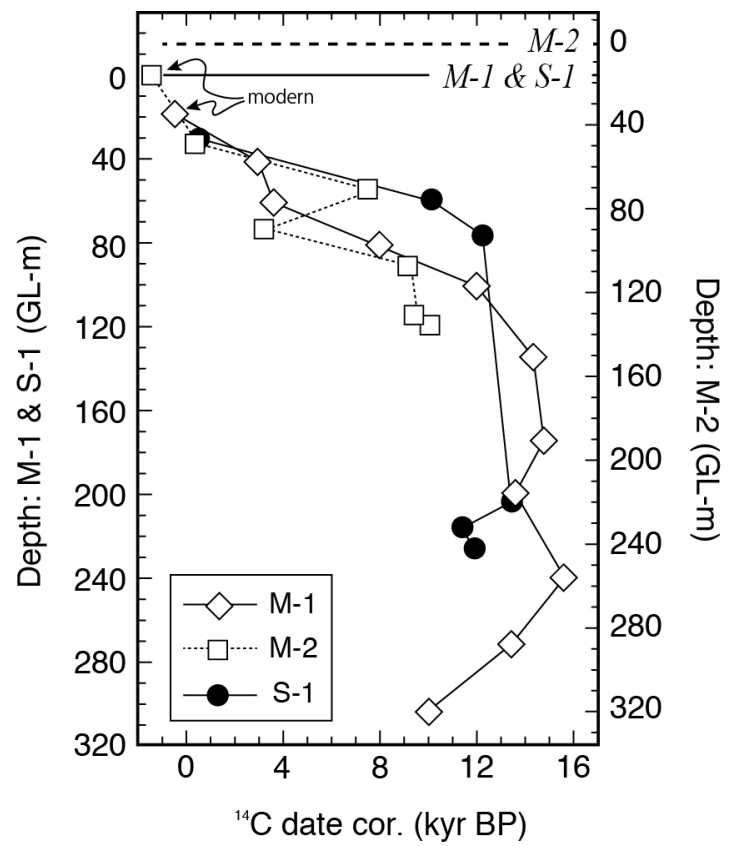

Figure 6 Vertical profiles of ${ }^{14} \mathrm{C}$ dates calculated from the corrected ${ }^{14} \mathrm{C}$ concentration (Miharu site: M-1 and M-2, Shirasawa site: S-1).

At depths deeper than $100 \mathrm{~m}$, the ${ }^{14} \mathrm{C}$ dates of $\mathrm{M}-1$ represent values identical to and older than those of M-2 and S-1, which is inconsistent with the hydraulic conditions. We consider shallow groundwater influence on ${ }^{14} \mathrm{C}$ dates to the lowermost depths of M-2 and S-1 on the basis of the following observations. The dips and strikes of fractures observed by the borehole camera (H Tsukamoto, unpublished data) suggest connections of fractures at those depths of M-2 and S-1 to neighboring valleys. In addition, the pressure increase in S-1 at $226 \mathrm{~m}$ (Table 2) indicates a large amount of shallow groundwater infiltration. Thus, the mixing of shallow groundwater is assumed at the lowermost depths of M-2 and S-1 with apparently young ${ }^{14} \mathrm{C}$ dates and ${ }^{3} \mathrm{H}$-free.

The ${ }^{14} \mathrm{C}$ dates at 271 and $302 \mathrm{~m}$ in M-1 indicate younger ages than that at $238 \mathrm{~m}$. Although the reason for this chronological reversal is unknown, it may be presumed that the fracture at the lowermost depth of M-1 connected to shallow depths. However, we can only suggest a possibility of inflow of young groundwater at the lowest part of M-1 because further hydraulic observation is required to prove this hypothesis.

The corrected ${ }^{14} \mathrm{C}$ dates represented the vertical gradients with depth (Figure 6) and range from modern to $\sim 10$ ka between the shallowest depth and approximate depths of $100 \mathrm{~m}$ at Miharu and $60 \mathrm{~m}$ at Shirasawa. The dates of shallower groundwater tend to be young, and these coincide with the appearance of ${ }^{3} \mathrm{H}$. Beneath these depths, the dates were relatively constant from 9140 to $15,580 \mathrm{yr} \mathrm{BP}$. When the sea level was lower during the glacial period than modern levels, the potential of shallow groundwater inflow to deep was high. After the glacial period, sea-level increases may have resulted in slower flow. Such changes occurred from deeper to shallower levels. Hence, the relatively constant ages may indicate that changes in groundwater flow rate and sea-level uplift occurred within a short period. 


\section{H A Takahashi et al.}

\section{CONCLUSION}

The present study reports the ${ }^{14} \mathrm{C}$ dates of groundwater sampled from fractures in granite obtained by 3 boreholes drilled at 2 sites in the Abukuma granitic province, northeast Japan. This analysis is the first to assign ${ }^{14} \mathrm{C}$ dates to groundwater in the Abukuma area. Both sites show contribution of dead-carbon contamination during storage in the fractures, which could be attributed to calcite, observed as veins in the drilling core and geogenic $\mathrm{CO}_{2}$, which likely ascended beneath the study area. The effects of dead-carbon contamination were corrected by using isotopic mass balance such that the $\delta^{13} \mathrm{C}$ values were assumed to be $-19 \%$ as initial carbon, and $-3.2 \%$ and $-4.5 \%$ as external carbon at Miharu and Shirasawa, respectively.

The ${ }^{14} \mathrm{C}$ dates range from modern to $\sim 16 \mathrm{ka}$. The dates were relatively constant at $10-16$ ka beneath 100 and $60 \mathrm{~m}$ from the ground surface at Miharu and Shirasawa, respectively. On the basis of ${ }^{3} \mathrm{H}$ and ${ }^{14} \mathrm{C}$ data, 1 borehole at Miharu indicated that the groundwater flow may not have been constant, although the deep inflow of shallow groundwater may have occurred simultaneously for respective fractures at depths between 60 and $100 \mathrm{~m}$. For depths deeper than $100 \mathrm{~m}$, the relatively constant ${ }^{14} \mathrm{C}$ date may have been influenced by rapid sea-level changes after the glacial period.

\section{ACKNOWLEDGMENT}

We are grateful to Mr Masaaki Takahashi, Ms Tomoko Ohta, Mr Akihiko Inamura, Dr Noritoshi Morikawa, and Dr Masaya Yasuhara for their assistance in the chemical and isotopic analyses and the groundwater sampling. We also thank 2 anonymous reviewers for their comments and suggestions. A part of this research project has been conducted as the regulatory supporting research funded by the Nuclear and Industrial Safety Agency (NISA), Ministry of Economy, Trade and Industry (METI), Japan.

\section{REFERENCES}

Ayraud V, Aquilina L, Labasque T, Pauwels H, Molenat J, Pierson-Wickmann AC, Durand V, Bour O, Tarits C, Le Corre P, Fourre E, Merot P, Davy P. 2008. Compartmentalization of physical and chemical properties in hard-rock aquifers deduced from chemical and groundwater age analyses. Applied Geochemistry 23(9):2686-707.

Berkowitz B. 2002. Characterizing flow and transport in fractured geological media: a review. Advances in $\mathrm{Wa}$ ter Resources 25(8-12):861-84.

Bird MI, Pousai P. 1997. Variations of $\delta^{13} \mathrm{C}$ in the surface soil organic carbon pool. Global Biogeochemical Cycles 11(3):313-22.

Bottomley DJ, Gascoyne M, Kamineni DC. 1990. The geochemistry, age, and origin of groundwater in a Mafic Pluton, East Bull Lake, Ontario, Canada. Geochimica et Cosmochimica Acta 54(4):933-1008.

Davidson GR. 1995. The stable isotopic composition and measurement of carbon in soil $\mathrm{CO}_{2}$. Geochimica et Cosmochimica Acta 59(12):2485-9.

de Dreuzy JR, Darcel C, Davy P, Bour O. 2004. Influence of spatial correlation of fracture centers on the permeability of two-dimensional fracture networks following a power law length distribution. Water Resources Research 40(1): W01502, doi:10.1029/ 2003WR00226.
Dewandel B, Lachassagne P, Wyns R, Marechal JC, Krishnamurthy NS. 2006. A generalized 3-D geological and hydrogeological conceptual model of granite aquifers controlled by single or multiphase weathering. Journal of Hydrology 330(1-2):260-84.

Gustafson G, Krásný J. 1994. Crystalline rock aquifers: their occurrence, use and importance. Applied Hydrogeology 2(2):64-75.

Gustafson G, Gylling B, Selroos JO. 2009. The Aspö Task Force on groundwater flow and transport of solutes: bridging the gap between site characterization and performance assessment for radioactive waste disposal in fractured rocks. Hydrogeology Journal 17(5): 1031-3.

Hoefs J. 2009. Stable Isotope Geochemistry. 6th edition. Berlin: Springer. 288 p.

Jouzel J, Merlivat L, Lorius C. 1982. Deuterium excess in an East Antarctic ice core suggests higher relativehumidity at the oceanic surface during the Last Glacial Maximum. Nature 299(5885):688-91.

Kamei A, Takagi T. 2003. Geology and petrography of the Abukuma granites in the Funehiki area, Fukushima Prefecture, NE Japan. Journal of the Geological Society of Japan 109(4):234-51. In Japanese with English abstract.

Keeling CD. 1958. The concentration and isotopic abun- 


\section{${ }^{14} \mathrm{C}$ Dating of Groundwater in Granite Fractures}

dances of atmospheric carbon dioxide in rural areas. Geochimica et Cosmochimica Acta 13(4):322-34.

Nakamura T, Niu E, Oda H, Ikeda A, Minami M, Takahashi H, Adachi M, Pals L, Gottdang A, Suya N. 2000. The HVEE Tandetron AMS system at Nagoya University. Nuclear Instruments and Methods in Physics Research B 172(1-4):52-7.

Neuman SP. 2005. Trends, prospects and challenges in quantifying flow and transport through fractured rocks. Hydrogeology Journal 13(1):124-47.

O'Leary MH. 1988. Carbon isotopes in photosynthesis. BioScience 38(5):328-36.

Ohwada M, Satake H, Nagao K, Kazahaya K. 2007. Formation processes of thermal waters in Green Tuff: a geochemical study in the Hokuriku district, central Japan. Journal of Volcanology and Geothermal Research 168(1-4):55-67.

Parkhurst DJ, Appelo CAJ. 1999. User's guide to PHRE-
EQC (Version 2)-A computer program for speciation, batch-reaction, one- dimensional transport, and inverse geochemical calculations. US Geological Survey Water-Resources Investigations Report 99-4259: 310.

Stuiver M, Polach HA. 1977. Discussion: reporting of ${ }^{14} \mathrm{C}$ data. Radiocarbon 19(3):355-63.

Tong P, Zhao D, Yang D. 2012. Tomography of the 2011 Iwaki earthquake (M 7.0) and Fukushima nuclear power plant area. Solid Earth 3(1):43-51.

Umeda K, Asamori K, Negi T, Kusano T. 2011. A large intraplate earthquake triggered by latent magmatism. Journal of Geophysical Research-Solid Earth 116: B01207, doi:10.1029/2010JB007963.

Zhang J, Quay PD, Wilbur DO. 1995. Carbon-isotope fractionation during gas-water exchange and dissolution of $\mathrm{CO}_{2}$. Geochimica et Cosmochimica Acta 59(1): $107-14$. 